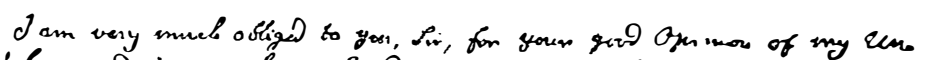

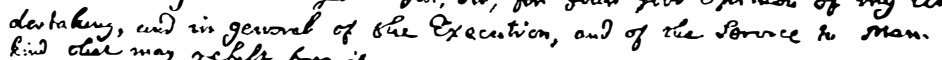

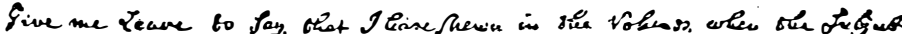

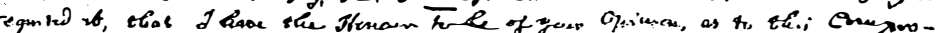

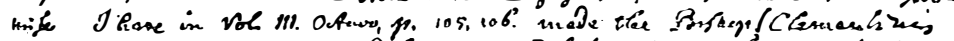

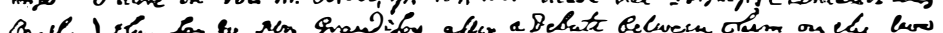

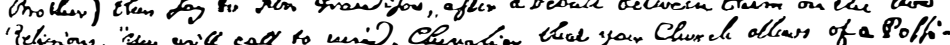

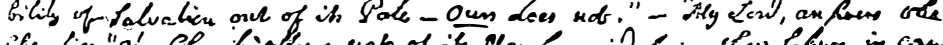

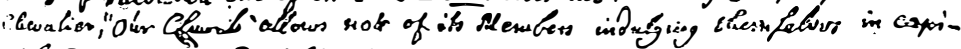
tof Enon, agasing Cemersictica."

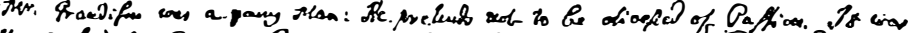

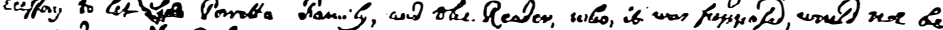

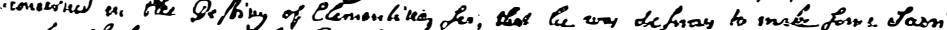

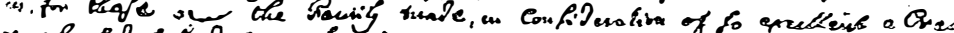

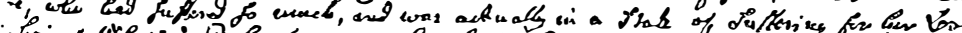

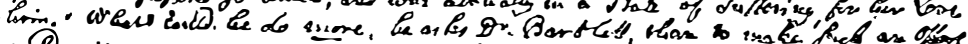

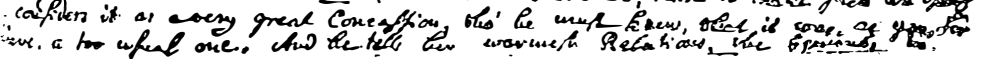
Samuel Richardsons håndskrift.

\section{RICHARDSON OG DEN MODERNE ROMAN}

\section{Claus Bratt Østergaard}

I drømmen betegner skrivetavlen en kvinde, idet den modtager indtrykket fra alle slags bogstaver.

(Artemidorus)

\section{Richardson - det moderne}

Det skal være fornøjeligt at læse, mente man i det 18. århundrede. Skal man i dag fornøje sig med lekture fra det 18. århundrede, kan man ikke gøre bedre end at gå til romanerne. Her kan man umiddelbart glæde sig over: Fieldings Tom Jones, Rousseaus Julie, ou la nouvelle Héloise, Goethes Werther, Sternes Tristram Shandy eller Diderots La Religieuse - for blot at nævne nogle af de vigtigste.

For andre af tidens centrale romaner er det imidlertid synligt, at de æstetiske kriterier har ændret sig. Det gælder eksempelvis Samuel Richardsons tre skelsættende romaner, Pamela, Clarissa og Sir Charles Grandison. Grandison har i dag kun litteraturhistorisk interesse og Pamela og Clarissa er, hver på deres måde, skrevet i et sprog, som den nutidige læser har svært ved at acceptere. Samtiden var dog begejstret (f. eks. Diderot) - skønt kritiske røster tidligt ytrede sig. Fielding, eksempelvis, satiriserede over Pamela i hele to romaner, Shamela og Joseph Andrews, og Voltaire bemærkede, at "jeg ville nødigt dømmes til at skulle genlæse Clarissa".

Men Richardsons to første romaner er ikke til at komme udenom. Clarissa rummer - trods sin alder og trods de godt 2000 sider, den forklarer sig igennem - helt nutidige indsigter. Og med Pamela opfindes en helt ny måde at skrive på. Derpå blev romanen model for andre romaner - ligesom dens heltinde (af nogle) blev model for et 
dydigt liv. Tekst og heltinde appellerede til samtiden (eller forargede den), og spørger man hvorfor, er svaret overalt det samme: Pamela værner om dyden i en verden, hvis værdier forfalder omkring hende. En moralsk begrundelse altså — åbenbart den kvalitet ved skriften, som udgjorde dens æstetiske tiltrækning.

Hver på deres måde skriver Defoe, Swift, Fielding og Voltaire indenfor den pikareske tradition. Men Richardson er anderledes. Han bryder med den rent additivt-episodiske fortællemåde og den sceniske betragtning af ydre hændelser - og vender sig mod følelse og moral for at udforske indre virkninger af ydre begivenheder. Gennem denne drejning af skriftens perspektiv udvikles en ny, 'psykologisk' dimension i teksten.

Dette indadrettede blik er ikke Richardsons opfindelse, naturligvis, men er essentielt i den katolske konfession og den protestantiske inderlighed. Hvad Richardson derimod opfinder er en ny formel for narrativisering af det indre blik. Vi kan tale om "en indre skrift" i hans romaner. Her er han beslægtet med Rousseau og (til dels) med Diderot (som i La Religieuse bygger på Richardsons skrift). Det er denne indre skrift, der gør de tre forfattere "moderne". Og det er det "moderne" ved skriften, jeg vil se på i denne artikel — og jeg har valgt at fokusere på Richardson fremfor på Rousseau, fordi han dels er "først ude" med den nye skriftform og dels fordi han skriver enklere - mere naivt - end Rousseau og dermed lader nogle omstændigheder ved sin skrift træde frem på en tydeligere måde.

Om Rousseau sagde Goethe, at med ham fødtes den moderne verden, ligesom den gamle gik til grunde med Voltaire. Men hvorledes moderne? må vi spørge. Rousseau reflekterer over en tid, der er under forandring - og han viser, at denne forandring giver anledning til en bestemt type af følsomhed, psykologi og moral. Hos Rousseau er det moderne ved skriften både gjort til emne og artikuleret som diskurs.

Denne dobbelte refleksion mellem tematisering og artikulation findes ikke hos Richardson. I modsætning til Rousseau gør han sig ingen overvejelser over arten af den diskurs, han betjener sig af, og bortset fra et banalt klagemål over tidens viderværdigheder har han ingen bevidsthed om konflikten mellem det moderne og det traditionelle. Tværtimod synes han at skrive på intuition alene:

Et følsomt sind, en kærlighed i konflikt med indre og ydre tilskyndelser som emne, en indlevende bevidsthed og en evne til med sin skrift at ramme omsætningspunktet mellem fortrolighed og offentlighed. Føjer man dertil en moral, der kan fungere som den instans, som det hele skal henvise til, da har man formlen for Richardsons talent.
Livet igennem var han puritaner og gik allerede som bogtrykkerlærling under øgenavnene "Gravity" og "Serious". Han var i øvrig et velanskrevet medlem af boghandlerstanden, gift to gange og levede uden voldsomme ydre begivenheder i sit liv.

Men der var denne lidenskab for at læse, berette og skrive. Som barn var han en efterspurgt historiefortæller blandt kammeraterne og i en alder af tretten år skrev han kærestebreve for flere unge damer, der havde opdaget hans talent. Her blandede det hele sig: fantasi, kærlighed og moraliseren - alt anlagt i et kvindeligt perspektiv.

Richardson skrev sin første roman (og i én forstand den første moderne roman) ved et tilfælde - uden forbillede af nogen art, og uden egentlig at gøre sig klart, hvilken tekstramme, han skrev indenfor. Faktisk var han i gang med noget helt andet. Han var nemlig blevet opfordret af et par kolleger i bogbranchen til at forfatte en manual i brevskrivning. Man forestillede sig forskellige "situationer" - og ville da have eksemplificeret hvilken skrift, der passede til hvilken situation. Disse Letters on Important Occasions udkom i 1741. Men midt i affatningen af manualen standsede Richardson op ved en "occasion", som åbenbart har betaget ham aldeles: "en ung pige udsættes for tilnærmelser fra herren i huset og skriver til sin fader herom". Brev fulgte på brev, situationen foldede sig ud og blev til handling, de enkelte breve blev til byggestene i konstruktionen af en narrativ formel - og Pamela udkom året før den manual, den var opstået igennem.

Vi kan forestille os brevteksten blive til romantekst, uden at Richardson spekulerer over meget andet end det drama der udfolder sig, mens pennen går over papiret. En genre-ubevidsthed, som modsvarer et bemærkelsesværdigt tekstligt balanceforhold mellem områder i det skrevne, som gøres til genstand for refleksion på den ene side - på den anden side andre områder som løber afsted i et skriftlag, som tilsyneladende er helt uafhængigt heraf (herom senere).

Hvorom alting er: Richardson havde opdaget en formel for en ny diskurs baseret på en kombination af tre dele: 1) den indre skrift, 2) en bestemt situation, 3) en narrativ sammenkædning af episoder, som transformerer den pikareske addition til en dramatisk akkumulation.

Formlen er en generator for skrift: episoden leder til et brev, brevet leder til refleksion, refleksionen udfoldes i en moralsk overvejelse, som atter igen skærpes gennem fornyede episoder. Samtidig kan det moralske kun demonstreres gennem at blive anfægtet - og anfægtelsens form er det ene køns konfrontation med det andet i et 
sceneri, som indeholder den nødvendige mængde vold til, at teksten får den energi, der kræves for at bære den igennem trods en episodisk énsartethed.

Pamela er en bemærkelsesværdig tekst - baseret i et blik, en moral og et kønsforhold: Blikket er i første omgang Mr. B's blik på Pamelas krop. Det spalter hende i en lystkrop (omend lysten er en andens) og en ånd (der kun er hendes fordi hun sætter sig imod) - og får hende til både at betragte sig selv og betragte det blik, der betragter hende. Moralen er hendes vægring mod at blive ét med det ønske, som blikket indeholder; hun vil holde stand for enhver pris herunder den pris, som teksten må betale ved at der også skrives hinsides, hvad moralen kan bære (herom senere). Fielding noterede dette som en utroværdighed ved teksten; men det er det utroværdige, som i dag gør romanen læselig, vil jeg mene. Kønnet giver teksten farve og figur; men det ene køns forhold til det andet er ikke blot emnet - fra indholdssiden baner kønnet sig vej til udtrykket, og teksten vibrerer med det pres, den udsættes for. Det hede blik, den kølige moral og det asymmetriske køn smelter sammen i en diskurs, hvor formen fusionerer med indholdet i en forbrænding af stilen og hvor selv sproget rødmer. Thi, som Pamela skriver til sin moder om en særlig nedrig streg fra Mr. B:

Hvilke ord skal jeg finde, min kxre moder (thi min fader bør ikke læse dette skrækkelige afsnit) til at beskrive resten - og min forvirring, da den nedrige slyngel (Mr. B/cbr) tog min venstre arm og holdt den under sin nakke og den nedrige skafferske (Mr. B's gobetween/cbø) holdt fast om min højre; og så greb hun mig rundt om livet... (Pamela, 178 (Everyman ed.)).

Pamela handler om det erotiske blik, og tekstens narrative puls er foranlediget af den kønsdans, som blikket sætter i værk. Dette blik er voldsomt og subversivt - det anfægter moralen og får kroppen til at sitre. Samtidig refererer det til moralen - giver den kød og blod og beskriver et sted, hvor den får mening. Her - i mødet mellem kønnet og moralen - opstår der en refleksion: i brevene beskriver Pamela, hvad der foregår på et handlingsplan. Samtidig tolker hun det, hun observerer. Teksten får to planer - ét for beragtning og ét for kommentar. Der, hvor teksten reflekterer, gø den det altså $i$ et moralsk register. Denne moralske refleksion fungerer autonomt i teksten - den er enkel, puritansk og ubevægelig og udgør et selvstændigt skriftlag.

Men her adskiller Richardson sig fra Rousseau. Franskmanden er lige så puritansk som englænderen (omend det puritanske bland- er sig med adskilligt andet) - men han er i stand til at reflektere over sin tekst. Og det er Richardson ikke. Richardsons refleksion er begrænset af den moralske orientering mod tekstens indholdsside - og transformeringen af kønnet til skrift ligger udenfor hans tekst-bevidsthed. Men det er netop gennem denne tekst-ubevidsthed, han udvikler et andet skriftlag, som ikke ved af, hvad der foregår i det første. Diskursen kommer til at indeholde "noget mere" - gennem det udvidede skriftrum, som vokser frem gennem narrativiseringen af køn og moral. Richardson ordner hele tiden sin 'skrift efter moralske kriterier. Men samtidig frembringer han en skrift, der ligger et andet sted end den moral, han påkalder.

Richardsons diskurs består altså af to skriftlag - ét der ved og ét der ikke ved. Diskursen er derfor paradoksal: den skal være både erfaren og naiv. Samtidig skal den være naiv om sin egen erfarenhed - ligesom den skal være naiv om de spaltninger, som den foranlediger. Fielding anklager derfor med rette Richardson for at tale med to tunger i Pamela. Men skelner man den subjektivitet, der intoneres af forfatteren som moralsk insisteren, fra den subjektivitet, som frembringes i diskursen gennem den udspaltning af "at vide", som finder sted - netop i kraft af naiviteten i den moralske position - da kan man se en "viden" i teksten selv omkring et fordelingsforhold mellem bevidsthed og ubevidsthed, som er helt moderne. Sagt med andre ord: den psykoanalytiske "opdagelse" er allerede forberedt gennem en bestemt type af diskursivitet, som Richardson (blandt andre) udvikler, mere end hundrede år før Freud der - af hensyn til kvindekønnets sarthed - forbød sin forlovede at læse Tom Jones.

Køn og moral smelter sammen hos Richardson i en særlig skriveforbindelse. Samtidig finder skriften sted i et rum af umiddelbart og sanset nærvær. Richardson skriver om det virkelige liv, understreger både Samuel Johnson og Diderot. Men den hverdagslige indsmeltning af køn og moral frembringer en hede i skriften, som en formmæssig (æstetisk) uro.

Jeg vil i det følgende kortfattet udskille disse tre dimensioner fra hinanden og se, hvorledes de forklares analytisk hos tre af Richardsons samtidige - det moralske hos Johnson, det kønnede hos Kant og den æstetiske uro hos Diderot. Men disse analytiske udsagn in mente vil jeg dernæst vende tilbage til Richardsons fortalte verden for at genoptage spørgsmålet om skrift og modernitet.

\section{Johnson - det moralske}

Fra omkring midten af det 18. århundrede vokser den moderne roman frem med fart og energi. Genren er ny - der er ingen model, 
ingen forskrifter, ingen poetik. Men det blev bemærket af kritikere, at noget nyt var på færde. Således Johnson, der gav den nye form nogle bemærkninger med på vejen i sit kulturkritiske énmandstidsskrift, The Rambler. Romanen interesserede i øvrigt ikke Johnson som form - selvom han altid forsvarede Richardson og hans værker. Men bemærkningerne i The Rambler er interessante, fordi romanen her kort bestemmes i tre analytiske parametre $-i$ forhold til en repræsentationsproblematik, $i$ forhold til en tidsproblematik og $i$ forhold til en moralsk (pragmatisk) problematik. Trods essayets kortfattethed og (relative) naivitet har vi her begyndelsen til den romanpoetik, som i øvrigt var fraværende i samtiden. Igen bemærker vi det naive, denne gang hos Johnson. En naivitet, der knytter ham til Richardson, og igen får os til at stille spørgsmålet om, hvorledes en naiv moralsk insisteren kan give anledning til en alt andet end naiv litterær skrift - som vi ser det i Pamela.

Men først Johnsons opfattelse af forholdet mellem kunst og virkelighed - repræsentationsproblematikken (første analytiske parameter). Her er Johnson en mand af sin tid, og han mimer den semiotik, som er kendt som imitationshypotesen. Kort fortalt betyder det, at der gælder et spejlforhold mellem udtryk (signifiant) og indhold (signifié) - mellem kunst og virkelighed: virkeligheden er fyldig, mangfoldig og sammenhængende (Leibniz) og kunsten re-præsenterer denne fylde $i$ et gendannet billede på det samme. Form og indhold stemmer overens, alt hvad der er virkeligt spejles som kunst, og al kunst spejler et virkeligt forhold. Dette på den ene side. På den anden side var Johnson moralist - og nok skulle sproget formidle det virkelige, men det skulle derudover underlægge sig en moralsk prøvelse og et didaktisk sigte:

Man mener med rette, at kunstens fornemste opgave er at efterligne naturen; men det er nødvendigt at udskille de dele af naturen, som bedst egner sig til efterlignelse: og endnu mere omhyggelig må man være, når man repræsenterer livet, som så ofte misfarves af lidenskaberne eller vanformes af ondskaben. Hvis verden fremstilles løsagtigt (promiscously), da ser jeg ikke, hvorfor man skal læse derom; eller hvorfor man ikke fuldt så vel kan betragte mennesket direkte, $i$ stedet for via et spejlbillede, som uden at gøre forskel viser alt, hoad man ser. (The Rambler, no 4, 31. 3. 1750).

På den ene side den neoklassicistiske repræsentationsopfattelse med det virkelige og dets spejlede aftryk i kunsten. På den anden side de problemfyldte dele af det virkelige - og den moral, der udskiller, peger på og evaluerer. Noget må holdes ude - lidenska- berne som misfarver og ondskaben, der vrider formen af led. Det virkelige ("nature") er derfor en svækket kategori - thi det indeholder mere end det bør. Netop bør. Dette "bør" vedrører et "for meget" i det virkelige. Når kunsten derfor - efter imitationshypotesen - gendanner og spejler, da må den tillige omdanne og skære bort. Johnson er dog ikke uden modsigelser i ovenstående citat. På den ene side er det virkelige der med kravet om genspejling — som han også bemærker i første linie. På den anden side altså alligevel ikke. Billedet truer hermed med at gå i opløsning. Og Johnson foreslår da også $\mathrm{i}$ sidste linie at gå direkte til det virkelige udenom det spejlbillede, som åbenbart ikke kan lade være med a indføje det løsagtige. Hermed er der gået kludder i virkelighedsbegrebet - såvel som i argumentationsgangen. Moralen bliver derimod tilbage med sit dictum og hævder sin egen sandhed som tilsidesættelse af andre regler end det sproglige påbud og det kunstneriske forbud.

Dernæst romanen som en ny måde at skrive på, en moderne genre (det andet analytiske parameter). Romanen er realistisk siger Johnson (og indleder dermed en diskussion om forholdet mellem skrift, genre og realitet, som kulminerede med knæsættelsen af realismen som poetikbegreb i Frankrig i 1830erne). Thi romanerne:

viser livet som det virkelig er, kun varieret af sådanne hændelser, som dagligt finder sted og alene paivirket af sådanne egenskaber og følelser som faktisk (really) forekommmer $i$ omgang med mennesker. (ibid).

Den nye genre ("comic romance") adskiller sig fra en "heroic romance" ved at være fri for usandsynlige tekstforestillinger ("the machines and expedients of the heroic romance"). Ingen kæmper der bortsnupper giftefærdige damseller, og ingen riddere til at føre dem tilbage til en ventende far. I stedet gælder at:

vore moderne forfatteres opgave er ganske anderledes...De er beskæftiget med portrætter, hvis original er kendt af enhver, således at enhver afvigelse fra en præcis gengivelse vil blive opdaget... (ibid).

Her argumenterer Johnson for, at den moderne romans fortrin består $i$ et anderledes tæt forhold til det virkelige end tilfældet var med en "heroic romance". Tekst og virkelighed er umiddelbart sammenlignelige. Det virkelige - graden af tæthed til det virkelige er kriterium. Men andetsteds var det sæde for det problematiske i 
den mimetiske proces. Ómkring det virkelige argumenterer Johnson $i$ to forskellige retninger. Han reflekterer over den forøgede mimetiske magt, som den moderne genre besidder. Samtidig spaltes argumentationen på dette forøgede virkeligheds- og modernitetsproblem.

Hermed er vi ved det egentlige analytiske parameter for Johnson - det moralske. Som vi så: det virkelige er spaltet i to dele - det sædelige og det løsagtige. Denne spalte gendannes i skriften - der deler sig efter det fremstillelige og det ufremstillelige. Denne repræsentationsakse krydser nu tidsaksen - og frembringer et skærpet moralsk problem. Thi med den moderne tids forøgede virkelighedsgengivelse forøges tillige faren for en suggestiv gengivelse af det løsagtige, som dermed bliver så meget mere problematisk:

Men hvis eksemplets magt (i den moderne roman/cbø) er så overbevisende, at det tager hukommelsen $i$ besiddelse med en art voldelighed og er $i$ stand til at frembringe effekter næsten uden viljens indblanding, da må man, når emnevalget er frit, bestræbe sig på kun at fremvise de bedste eksempler; og det, som udøver en stærk virkning, bør ikke være ondsindet eller ubestemt $i$ sin virkning. (ibid).

Faren er altså, at den problematiske del af den spaltede virkelighed iklæder sig et moderne formsprog. Thi, som Johnson skriver, så virker den æstetiske form uafhængigt af viljen — og det er i viljen moralen har sæde. Det er bemærkelsesværdigt, at Richardson i et efterskrift til Clarissa gør sig lignende overvejelser over forholdet mellem æstetik, moral og virkelighed - men at han i øvrigt har ladet det moralske være det, der iklæder sig den æstetiske form - og dét ikke for at bedrage en vilje, som ikke vil vækkes, men tværtimod for at kunne simulere gennem virkelighedsformen, så det moralske budskab glider ned:

I en tid præget af fornøjelser og udsvævelser måtte det være onskeligt for en forfatter, der ville udforske kristendommens storslåde lære, at han kunne liste sig til at blive iklædt en moderigtig klædedragt; således ville han kunne opnå, hvad han havde til hensigt...(Clarissa, IV, Postscript).

Hvor Johnson frygter, at det virkelige skal smyge sig udenom viljen til moralsk domfældelse i kraft af den æstetiske forms blændværk, dér ser Richardson en mulighed for at opnå en moralsk hensigt gennem et æstetisk bedrag. En forskel i synsvinkel mellem en forfatter og en moralist. Skal man bedrive simulation? eller skal man udøve censur? Richardson er her tro mod sin egen skrift (som netop handler om gode miner til slet spil). Johnson vælger omvendt at rose Richardson i et sprog, der er iklædt en militær metaforik:

forfatter, som har udvidet vor forståelse af den menneskelige natur, og som har lært lidenskaben at følge dydens kommando...(cit fra Boswells Life of Johnson, A.D. 1750)

\section{Kant - det kønnede}

Men man kan også læse Johnsons rosende ord om Richardson baglæns. Altså: ingen dyd uden kommando og ingen tøjler om lidenskaben uden en fremvisning af det tøjlesløse. Og fremvisningen er skriftens anliggende - netop den maske, som Richardson indsmyger sin moral i - uden rigtigt at være opmærksom på, at klædedragten må forvandle hans hensigter. Men skriften skal bevæges for et indre øje og må have form og figur. Denne form er kønnet og den kvindelige figur bliver Richardsons skriftsted. Men lad os nærme os Richardsons narrativiserede kønsforhold indirekte gennem at betragte en analytisk diskurs - Kants antropologiske overvejelser over kønnet. Hvorledes sammenhængen er mellem den narrative og den analytiske diskurs vil da kunne antydes.

Mennesket, siger Kant, er delt mellem natur og kultur og kan studeres i begge dimensioner. Læses mennesket kulturelt hedder studiet pragmatik - og pragmatikken rummer studiet af kønnet som delområde. Her må man — da det drejer sig om videnskabelighed — gå systematisk til værks og fastlægge de almene træk ved det ene køns forhold til det andet. Sådanne træk findes nemlig, og Kant opregner dem på en halv snes sider i sin Anthropologie in Pragmatischer Hinsicht fra 1798.

Kants diskurs er analytisk - det gælder om at fastlægge et vidensforhold, og han er bevidst om kilder og fejlkilder. Det forhindrer dog ikke, at hans fremstilling af stoffet tillige er baseret i en grundmetafor om det kvindelige og det mandlige, som i sin tur reflekteres i en anden metafor over naturen og kulturen. Under dække af anekdoter, forbehold og den neutralt analytiske syntaks, som de almene pointer indføres i, er Kants præsentation fremstillet gennem en indirekte narrativisering af denne grundmetafor. Det skal han ikke kritiseres for - kønnet er næppe (semiotisk) begribeligt uden at blive narrativiseret. Men samtidig er han forpligtet på det videnskabelige - det narrative stof skal hele tiden fremtræde som analyse. Det giver nogle diskursive forskydninger - og den egentlige pointe kommer til at ligge i tekstens yderkant, som vi skal se. Men tilbage til Kant og kønnet. Analysen gælder det interessante ved det 
hele - kønnets diakritiske mærke, sættelsen af forskellen overhovedet. Det forskellige er kvinden - og det er gennem at rette blikket på hende, konstruktionen bliver synlig. Denne konstruktion er væsentlig, thi den er ikke alene modelleret over det kritiske spil mellem naturlige og kulturlige kræfter - men er en akse, hvorom selve kulturen vokser frem af det mere primitive natursubstrat.

Metaforen, altså: kvinden er en SVAG maskine, relativt set, siger Kant. Skal denne maskine yde det samme som en stærkere mandlig maskine, da må den besidde mere KUNST. Og sådan er det. Naturen - som her handler efter FORNUFTEN - giver kvinden en svag krop, men forvandler den samme naturlige svaghed til styrke ved at gøre svagheden til kunst (kunnen) indenfor en kulturel dimension. Kvindens svaghed er derfor hendes styrke - og det er tillige hendes kunst at give sin gunst uden at forråde sin hemmelighed:

Manden er let at udforske, men kvinden forråder ikke sin hemmelighed.. Kvinden UNDSLAR sig manden BEJLER; hendes underkastelse er hendes gunst. (Anthropologie in Pragmatischer Hinsicht, "Der Charakter des Geschlechts".)

Dette ligner endnu et bon mot fra århundredets righoldige reservoir af almindeligheder. Men Kant peger på konsekvensen for det menneskelige begær: det udvikler sig forskelligt for de to køn, men for begge gælder, at begæret må spaltes. Kun derved kan det naturlige triumfere som kulturel forfinelse - og antropologien må i denne sag især interessere sig for hende, siger Kant:

Idet naturen $i$ fosteret har betroet sit dyrebareste pant, nemlig arten, til det kvindelige skød, $i$ kraft af hvilket hun skal sørge for slægtens fortsatte forplantning og forevigelse, da frygtede den derigennem for dets bevarelse og indplantede denne FRYGT - nemlig for KROPSLIGE overgreb og en ængstelighed for deslige farer $-i$ hendes natur; gennem en sådan svaghed anmoder dette køn retmæssigt det mandlige køn om beskyttelse. (ibid).

Kvindekroppens naturlige skønhed vækker mandens (naturlige) begær. Men den samme krops skrøbelighed indplanter kulturel ængstelighed hos hende og kulturel hensyntagen hertil fra hans side. Mandens begær deles derfor i en uhæmmet naturkomponent og en hæmmende kulturkomponent, der (som anden natur) vender sig mod naturen, bemestrer den og civiliserer den. Men hvad er det kvindelige begær? Ja, Kant svarer - som senere psykoanalysen at kvinden begærer at blive begæret. Hun begærer ikke NOGET, men NOGET ANDET - nemlig sig selv som objekt for det hanlige blik. Helt så dialektisk formulerer han det ganske vist ikke - det måtte vente på Hegel - men han taler om, at det er det kvindelige begær at lokke alle mænds blikke til sig.

Som vi ser: den kvindelige kunst er en kunstfærdighed, der forvandler sig til manøvrer og spil. Det gælder en bestemt måde at fremtræde på. Disse fremtrædelsesformer er natur og krop - men udformet som udsmykket kunstighed og i et kulturelt regi. Fremtrædelse er dermed simulation - og Kant forsvarer kvindens hang til koketteri. At det udformes som simulation forbliver en antydning hos Kant - i yderkanten af hans tekst. Hos Richardson er det centralt. Men kun i det ene af diskursens to skriftlag. I det andet pukkes på det renfærdige og det autentiske. Richardsons to skriftlag viser noget om et ansigt og den maske, der dækker sig bag det. Her er alt vendt om og alt er på skrømt — og hvem kan da vide sig sikker?

\section{Diderot - det æstetiske}

Med den moderne roman opstår en ny udtryksmulighed, siger Johnson, det skyldes, at sproget her er tættere på virkeligheden end i nogen tidligere skrift. Og det betyder igen, at det virkelige bliver mere påtrængende i skriften end nogensinde. For Johnson er det virkeliges forhold til den ny skrift derfor tvetydigt: der er en mulighed for overbelastning af skriften - moralen må mobiliseres under dydens kommando. Men moralen kan omgåes, fordi den æstetiske form er blevet så suggestiv i den nye stil, at viljen (som instrument for moralen) ikke når at opdage noget. Derfor denne ængstelse for, at moral og æstetik falder fra hinanden - og at det virkelige omdannes til det groteske, der usurperer den litterære skrift.

Også Diderot noterer den intensiverede imitationsmulighed, som indeholdes i Richardsons nye skrift. Men for Diderot er dette en sproglig ekspansion, som medfører et endnu uset forhold til sandheden. Indtil nu har sandheden været begrænset til maximens almene form, men med Richardson bliver det sande sanseligt og konkret:

Alt det, som Montaigne, Charron, la Rochefoucauld og Nicole har formuleret $i$ maximer, dét har Richardson udtrykt som handling. (Éloge de Richardson).

Maximen er en abstrakt og generel adfærdsregel, siger Diderot videre. I sig selv efterlader den intet sanse-billede i bevidstheden. Anderledes med Richardsion og den nye skrift: 
Men ham, der handler, ham ser man, man stiller sig ved hans side eller indtager hans plads, man er lidenskabeligt for ham eller imod ham. Man tager hans rolle på sig, hvis han er dydig; man viger fra ham, hvis han er lastefuld. Findes der nogen, som ikke har ladet sig ryste af en Lovelace eller en Tomlison? (ibid).

Richardsons skrift henvender sig direkte til følelsen. Herved bliver sandheden på én gang mere sanselig og mere sandfærdig. Det nye er tekstens billede og den måde, det griber læseren på. Her formidler følelsen sig direkte - det går fra det skrevne ord uhindret over i den læsendes krop. Med eller mod sin vilje, siger Diderot, får læseren - der netop er grebet af tekstbilledet - en rolle i romanen: man bliver deltager i samtalen, man uddeler ros og ris, man beundrer og forarges. Den nye skrift hensætter læseren i en tilstand af følelsesmæssig agitation. Thi sandheden får gennem den formmæssige konkrethed en direkte relation til den enkelte. Det sande bliver det subjektive - og det er fusionen mellem sandhed og subjektivitet, der melder sig som følelsesmæssig oprørthed. Således også med Diderot selv. I et brev til Sophie Volland beretter han, hvorledes læsningen af Clarissa havde betaget ham:

Hvad de siger om Clarissas begravelse og testamente, er jeg helt enig $i$. Det er blot endnu et bevis på vore sjæles overensstemmelse. Atter fyldtes mine øjne med tårer. Jeg kunne ikke lase videre, jeg gav mig til at fortvivle, jeg henvendte mig til broderen, til søsteren, til faderen, til onklerne, jeg talte ganske højt og til stor forbløffelse for Damilaville, som intet forstod hverken af min ophidselse eller af min tale og som spurgte mig, hvem jeg var vred på. (Correspondance inédit, t. I, p. 155).

Clarissas imaginære slægtninge apostroferes direkte af Diderot under læsningen. Han er blandt dem. Til gengæld er han ikke længere sammen med Damilaville. Diderots opfattelse af den verden, som kunsten frembringer, er altså den modsatte af Platons, hvor billedet blot er en afglans af noget mere virkeligt. Her er det omvendt: det kunstneriske billede er mere end virkeligt - og den sandhed, der garanterer det, er af sanselig karakter. Diderots egen Éloge til Richardson er i øvrigt skrevet i en serie eksklamationer. Stilen er superlativets og udråbstegnets - tekstudbrud, der vidner om at udtrykssystemet søger ud mod grænsen af, hvad det kan formidle. "Oh Richardson!" skriver Diderot - og han gentager det, idet kun gentagelsen kan forstærke udtrykket. Ligesom Richardsons tekst har grebet Diderot, griber han selv sproget og presser det maximalt.
Stilen bliver ekstrem og sproget bliver svimmelt. Hvad der skal repræsenteres ligger hermed hinsides imitationshypotesens nøje spejling af ethvert punkt $i$ det virkeliges flade som et tilsvarende punkt $i$ tekstfladen. Udtrykket er blevet agiteret af følelsen - og den virkelighed, som allerede Johnson noterede et "for meget" af, kan ikke længere gengives som kun et billede af noget virkeligt, men må være mere sand end blot sandfærdig. Men sandheden er subjektiv, den finder sit udtryk i følelsen og den opleves gennem kunsten: signifianten slider sig løs fra sin signifié - og refererer i stigende grad til sig selv. Denne selvreference er en formel for et skuespil — og vi er tilbage ved simulationen.

\section{Richardson - det dydige}

Handlingsgangen i Pamela kunne ikke være enklere. Den består nemlig blot i en ekspansion med variationer af den før omtalte grundsituation mellem forfører, datter og fader (og moder). Handlingen udspilles mellem Pamela og Mr. B - faders og moders rolle er alene at læse de breve, som Pamela sender til dem og hvori handlingen genspejles. Disse breve er tillige romanens tekst - og læseren placeres på de ængstelige forældres intime lyttepost. Mr. B er i første omgang repræsentant for Kants første natur. Han er (stort set) uden hæmninger og efterstræber Pamela med den kraft, der ligger $\mathrm{i}$ den viriliserende naturlov. Mr. B er altid i bevægelse - aggressiv, udfordrende og utilfreds med Pamelas uvillighed. Og hun - afværgende, i flugt, passiv og i en permanent apostrofe til sin egen dyd, hvis magi synes at kunne sætte det hele i værk.

Dette er - langt hen i teksten (indtil Mr. B fortryder sin første natur og lader sig civilisere i den andens regimente) - indholdet $i$ grundsituationen mellem forfører og (næsten) forført. Han angriber, hun flygter. Fra den ene episode til den næste. Og igen. De bevæger sig rundt på hans gods fra værelse til værelse - fra bibliotek til køkken, fra køkken til salon - herfra tilbage til biblioteket. En kønnet dans der folder sig ud, baseret i hans angreb og hendes flugt $\mathrm{i}$ den grad, at andre kvaliteter ved de to synes at forsvinde.

Men Pamela flygter også til sit kammer, hvor hun nedskriver, hvad hun just har været igennem til forældrene. Men samtidig med, at hun fatter pennen for at skrive, er hun på vagt for Mr. B, som lurer ude i omkredsen af hendes private rum. Hun skriver om, at hun er beluret og at hun hvert øjeblik kan forvente nye angreb. Hun beretter om sin flugt - og hun beretter om de breve hun skriver.

Hermed indføres i teksten en bevægelighed mellem den observerede situation og et punkt for betragtning og refleksion. "Situationen" spejles i brevet (som i Letters), men spejlingen i brevet er selv 
en del af en situation, som spejles. Pamela skriver om, at hun flygter. Men hun skriver også om, at hun skriver. Skriften fordobler sig.

Denne fordobling svarer til en fordobling mellem at vide og ikke at vide: Pamela flygter op på sit kammer og hengiver sig til sit private forehavende (at skrive). Hun er alene - naiv, uvidende og skriver enkelt og uskyldigt. Samtidig er hun under observation. Hun ved det ikke. Men ved dog gennem sin skrift, at det er muligt. Hun skriver i fortrolighed til sine forældre. Brevene bliver opsnappet af Mr. B. Hun skriver herom til forældrene - beretter, at brevene til dem om Mr. B er blevet læst af Mr. B. Og hun fortsætter med at skrive - i en spejlforførelse, som udvikler sig ved siden af den første forførelse. Noget sker, som finder vej til brevene. Men forskudt, som gentagelse og fordobling - i et tredie øje, som teksten selv indfører til sin egen afluring.

Vi kan da forstå grundsituationen som en analyse af et vidensforhold. Nærmere bestemt en grænsedragning mellem hvad der kan vides af hvem - og i hvilket sprog, der kan redegøres for det. Pamela selv spalter sig gennem skriften. På den ene side er hun den beskrevne krop, som spejles i Mr. B's blik og i dets tilbagespejling i brevet (den gamle opgave: hvilken situation afføder hvilken skrift?). På den anden side er Pamela skrivende subjekt, hun fører pennen, der registrerer det blik, der objektgør hende. Pamela er selv en dobbelt refleksion - hun er noget, men i samme øjeblik er hun noget andet. Hun er simulation. Men til simulationens væsen hører ikke at give sig til kende. Derfor bevæger hun sig hele tiden over i den position, der forskubbes når den anden position markeres. Hun er et subjekt, der fremtræder som objekt. Eller hun er et objekt for et andet tekstsubjekt end det, hun selv intonerer i brevene.

Hvis Richardson er naiv, er hans tekst det ikke. Der er flere lag i teksten - og det er den diskursive kontrast mellem dem, der så glimrende illustrerer det skrivende subjekts forskellige jeg'er.

Omkring 1743 producerede Joseph Highmore en serie på tolv malerier, som skildrer handlingsgangen i Pamela. Richardson var begejstret, og går man malerierne efter, forstår man hvorfor: de forekommer ganske kongeniale med romanteksten - og det i forhold til begge skriftlag. På den ene side den tematiske understregning af det velanstændige og det dydige hos heltinden. På den anden side besidder malerierne også en impressionistisk fornemmelse for øjeblikket og en tonus og glød i farven, som antyder, at der udover indholdet er malet et skin.

Specielt ét billede er interessant, fordi det rammer selve grundsituationen - og dermed tekstens nerve. Pamela sidder i et værelse (biblioteket? sit lønkammer?) på Mr. B’s herregård ved et skrivebord (som i maleriets perspektiv bliver ovalt og dermed gentager rokokkoens konventionelle forbindelse mellem ovalen, portrættet og det kvindeligt-erotiske). Hun er just ved at skrive et af sine breve. Hånden holder om fjerpennen og svæver over papiret. Bevægelsen er opstandset - sceneriet angiver et fotografisk nu. Pamela er i gang med sit - men er blevet afbrudt. Hendes blik er opmærksomt og lyttende i en slags ængstelighed, som endnu ikke er blevet til angst. Det er mere, som lytter hun efter noget allerede bekendt - en lyd, der kan bekræfte sandheden af, hvad brevet fortæller. Hendes krop og blik er anspændt, vidende om det, der (måske) er ved at afbryde hende. Det er denne viden, der gentages i brevet - hvad betragteren ved ligesom Mr. B ved det - og som billedligt er gentaget på et maleri, der hænger bag hende på væggen, hvor en dånet kvindeskikkelse fremviser et blottet bryst, mens en mandsskikkelse bøjer sig ind over hende.

Men samtidig er hun uvidende - grebet midt i sin privathed, dér hvor hun kan forrette, hvad der alene vedrører hende. Blækhuset på skrivebordet er slået op. Også vinduet til biblioteksskabet står på vid gab, og brevarkene er skubbet ind over hinanden under den suspenderede pen i Pamelas højre hånd - mens andre ark, uordentlige og krøllede, skubbes til side af Pamelas venstre hånd, mens hun ser til den anden side.

Lyset fanger Pamela i billedets centralfelt og fæstner sig på hendes hvide hud, som træder stærkt frem. Lyset fanger også det hvide stof i hendes hovedkappe, kraveparti, kjoleliv, ærmer og forklæde. Resten af kjolen folder sig om hende som en kappe og indrammer hende i en sort kontrast. Bag hende omsluttes hun af rødbrune og varme farvetoner fra træpanel, bord og vinduesrammer.

Pamela er i høj grad en visualiserbar tekst, og Highmore kan både illustrere teksten og gengive en ekstra uro i tolkningen. I centrum for blikket sidder Pamela. Det fanger hende - som lyset gør det - og påfører hende den uro, som opstår i mødet mellem den private fordybelse og det voldelige indgreb, som er overraskelsens essens. Revet ud af sig selv stivner hun i et øjeblik i en positur (som maleriet gengiver smukt), hvor hun er ude af sig selv - en ekstase, en agiteret kvindelig form, som kan bevæge Diderot.

Men samtidig er ekstasen under kontrol og den agiterede krop behersket af en indre vilje. Blikket fra Mr. B baner sig vej frem mod hendes krop og deformerer den momentant. Men derfra løber energien i sceneriet videre gennem den svævende pen ned i skriften hvor det hele fryses og bliver til viden. Ikke blot en viden om Mr. B og de viderværdigheder, Pamela udsættes for, men en viden om selve omsætningsforholdet mellem blikket og skriften. Thi Pamela 
ved. Og dog ved hun ikke. Hun skriver om, hvad der foregår. Samtidig foregår der mere, end hun skriver om. Skriften løber af sted af sig selv, synes det, og farves af den kønstone, som udsvedes af de rene hensigter.

Men hvori består det moderne i Pamela? I selve diskursens,karakter, vil jeg mene. At være eller ikke at være...At vide eller ikke at vide...At vide, at man ikke ved...Ikke at vide, at man ved... I Pamela tegner skriften et spor, som psykoanalysen senere trådte $\mathrm{i}-$ uden at gøre sig klart, at sporet var skrift og nedtrådt allerede længe inden Freud genopdagede det med sin semi-analytiske og semi-narrative sprogbrug.

Lad os navngive denne skrift - og lad os gøre det kongenialt og kalde den $d y d$. Dyd er et sted for mening. Richardson intonerer den - og den făr hans skrift til at vibrere.
Men ei ved dette Fremperiot ftod yan fitlle,

Tlyi ved en fongeliy Eonfirmation

Fil finidot bin overfart pan fin \$erfon

(Da ei ber meer var llofigt til, at \$ille

\$ele iman Baroner ymn veyave vilde)

Den lrenglt: foronste Titel af Baron,

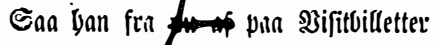

şaron og Simmerberre Şomo fretter.

Bed famme Tidozpunet bavoe yan den oblade,

Aft fore frem i sttlaft, buibt fom Snee,

De tuende bulde Dettre, og at pee

Dem ejrept og fmilende for sfftrct trede: *

Bettine med en fuenfe Brets Miagnuz (Bjede,

Dg Sulle med en norfe Particulier;

Shorbed yan laave gjort lojad lyan formanede,

For faft at enutte Slandinavienz Traade.

w.

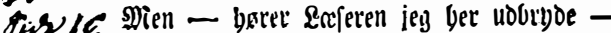

¿mass" Mien yoad leeplitte ban den lange Tid?

San virleo! (Caa maa Euaret ber jo (yoe)

Jjan sireed unfludelig! .5anz \$o

siar ilfe blot Formsielfet at nyde,

Sipn on at gaune Şerden ved jin Flid.

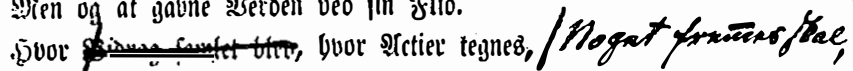

Swa baim, bark siatn, banz slung ber punde regnes.

\section{Japhiete}

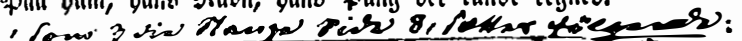

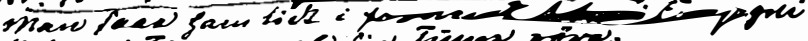

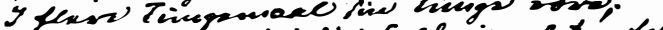

thaw feas fand, i fin folvoring ext g fari,

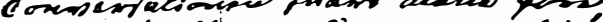

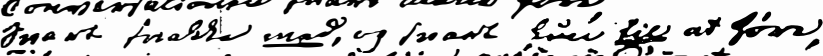

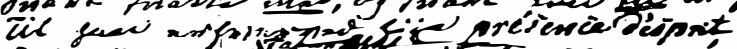

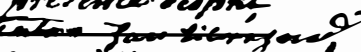

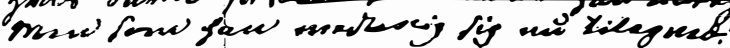

Paludan-Müllers korrektur af Adam Homo. 